\title{
A COMMENTARY ON THE COLLECTED PLAYS OF W. B. YEATS
}


Also by $A$. Norman Jeffares

A COMMENTARY ON THE COLLECTED POEMS

OF W. B. YEATS

TRINITY COLLEGE, DUBLIN: DRAWINGS AND

DESCRIPTIONS

W. B. YEATS: MAN AND POET

OLIVER GOLDSMITH

THE POETRY OF W. B. YEATS

GEORGE MOORE

THE CIRCUS ANIMALS: ESSAYS

\section{Edited works}

MARIA EDGEWORTH, CASTLE RACKRENT AND

OTHER STORIES

BENJAMIN DISRAELI, SYBIL

BENJAMIN DISRAELI, LOTHAIR

SEVEN CENTURIES OF POETRY

THE SCIENTIFIC BACKGROUND (with M. Bryn Davies)

POEMS OF W. B. YEATS

SELECTED POEMS OF W. B. YEATS

A GOLDSMITH SELECTION

COWPER

SELECTED PROSE OF W. B. YEATS

SELECTED PLAYS OF W. B. YEATS

SELECTED CRITICISM OF W. B. YEATS

IN EXCITED REVERIE (with K. G. W. Cross)

GOLDSMITH, SHE STOOPS TO CONQUER

WHITMAN, SELECTED POEMS AND PROSE

CONGREVE, INCOGNITA AND THE WAY OF THE WORLD

SHERIDAN, THE RIVALS

SHERIDAN, THE SCHOOL FOR SCANDAL

FAIR LIBERTY WAS ALL HIS CRY

CONGREVE, LOVE FOR LOVE

FARQUHAR, THE BEAUX' STRATAGEM

SWIFT

FARQUHAR, THE RECRUITING OFFICER

SCOT'T'S MIND AND ART

RESTORATION COMEDY

Also by $A$. S. Knowland

SIX CAROLINE PLAYS (editor) 


\section{A COMMENTARY ON \\ THE COLLECTED PLAYS \\ OF W. B. YEATS}

A. Norman Jeffares

and

A. S. Knowland 
(C) A. Norman Jeffares and A. S. Knowland 1975

Softcover reprint of the hardcover 1st edition 1975

All rights reserved. No part of this publication may be reproduced or transmitted, in any form or

by any means, without permission.

First published 1975 by

THE MACMILLAN PRESS LTD

London and Basingstoke

Associated companies in New York

Dublin Melbourne Jobannesburg and Madras

SBN 333120426

ISBN 978-1-349-01078-3

ISBN 978-1-349-01076-9 (eBook)

DOI 10.1007/978-1-349-01076-9 


\section{For Frank Wynne}

$$
\text { and all our friends in Sligo }
$$




\section{Contents}

PREFACE ix

ABBREVIATIONS $\quad$ x

CHRONOLOGY OF YEATS'S LIFE $\quad$ xv

THE CONTENTS OF THE COLLECTED

$P L A Y S \quad$ Xxiii

COMMENTARY I

APPENDIX I: GAELIC NAMES 3II

APPENDIX II: DIAGRAM FROM $A$ VISION 312

INDEX TO TITLES 313

Maps

YEATS'S IRELAND

$\mathbf{x x v}$

YEATS'S SLIGO

xxvi 


\section{Preface}

Thrs commentary is intended to assist the reader of Yeats's Collected Plays (page references to this work are given in the margin in bold face type). Yeats's poetry and his prose have been quoted where they throw light on the meaning of particular plays: thus his notes to various editions are included as well as passages from his critical and autobiographical prose and from his letters.

Readers will be able to supplement the bibliographical information by referring to The Variorum Edition of the Plays of W. B. Yeats (ed. R. K. Alspach). A Concordance to the Plays of W. B. Yeats (ed. Eric Domville) affords a quick means of comparing the language, the images and symbols used by Yeats. A useful guide to published criticism of Yeats's work is $A$ Bibliography of Yeats Criticism 18871965 (ed. K. G. W. Cross and R. T. Dunlop).

Stirling

Oxford

I974
A. Norman Jeffares

A. S. KNOWLAND

The quotations from the work of W. B. Yeats are reprinted by kind permission of Senator Michael Butler Yeats. 


\section{Abbreviations}

BOOKS BY YEATS

$A$ Autobiograpbies (1955)

$A V(\mathrm{~A}) \quad A V i s i o n$ (1925)

$A V$ (B) $\quad A$ Vision (1937)

CK The Countess Katbleen and Various Legends and Lyrics (1892). (In Poems (1895) and subsequent printings the spelling Countess Catbleen was used)

Comm A. N. Jeffares, $A$ Commentary on the Collected Poems of W. B. Yeats (1968)

CP Collected Poems (1933; 2nd ed., with later poems added, 1950). References are to the second edition unless otherwise stated.

CPl Collected Plays (1934: 2nd ed., with additional plays, I952).

CT The Celtic Twilight (1893)

CW Collected Works (1908)

DP Dramatis Personae (Dublin, 1935; London, 1936). The latter edition includes Estrangement, The Death of Synge and The Bounty of Sweden.

DWL Letters on Poetry from W. B. Yeats to Dorotby Wellesley (1940; reissued 1964). References are to the 1964 reissue.

E Explorations (1962)

E\& I Essays and Introductions (196I)

EPS Early Poems and Stories (1925)

FMM A Full Moon in March (1935)

FPFD Four Plays for Dancers (1921)

KGCT The King of the Great Clock Tower (1934)

$L$

Letters, ed. Allan Wade (1954)

LHD The Land of Heart's Desire (1912)

$M$

$M S$

Mythologies (1959)

Memoirs, ed. Denis Donoghue (1972) 
xii $\quad A$ Commentary on the Collected Plays of W. B. Yeats

OTB On the Boiler (1939)

$P$ (1895) Poems (1895)

$P A I T \quad$ Plays for an Irish Theatre (I9II)

$P A S L \quad$ Per Amica Silentia Lunae (1918)

PC Plays and Controversies (1923)

PPV Plays in Prose and Verse (1922)

RPP Responsibilities: Poems and a Play (1914)

SSY The Senate Speeches of W. B. Yeats, ed. Donald T. Torchiana (1960)

TCM The Cat and the Moon and certain poems (1924)

TSR The Secret Rose (1897). There was an enlarged and revised edition in 1902 . References are to the 1897 edition.

VE The Variorum Edition of the Poems of W. B. Yeats, ed. Peter Allt and Russell K. Alspach (1957)

$V P l \quad T$ The Variorum Edition of the Plays of W. B. Yeats, ed. Russell K. Alspach (1966)

$W$ or $B \quad$ Wheels and Butterflies (1934)

WR The Wind Among the Reeds (1899)

WWP The Words upon the Window-pane (1934)

OTHER BOOKS

AL Lady Wilde, Ancient Legends, Mystic Charms and Superstitions of Ireland (1887)

CM Lady Gregory, Cucbulain of Muirtbemne (1902)

ED Richard Ellmann, Eminent Domain (1967)

ICL Birgit Bjersby, The Interpretation of the Cuchulain Legend in the Works of W. B. Yeats (1950)

IDM Una Ellis-Fermor, The Irish Dramatic Movement (1954)

IP D. J. Gordon, W. B. Yeats, Images of a Poet (196I)

IY Richard Ellmann, The Identity of Yeats (1954)

J Lady Gregory's Journals, 1916-1930, ed. Lennox Robinson (1946)

LT T. R. Henn, The Lonely Tower (1950; rev. ed. 1965). References are to the 1965 edition.

LTHS John Butler Yeats, Letters to bis Son W. B. Yeats and others (1944)

MLD John Rees Moore, Masks of Love and Deatb (1971) 
PYP George Brandon Saul, Prolegomena to the Study of Yeats's Poems (1957)

PYPl George Brandon Saul, Prolegomena to the Study of Yeats's Plays (1958)

RI Frank Kermode, Romantic Image (1957)

Sers Thomas R. Whitaker, Swan and Shadow: Yeats's Dialogue with History (1964)

SQ Maud Gonne MacBride, $A$ Servant of the Queen (1938)

TD Leonard E. Nathan, The Tragic Drama of W. B. Yeats (1965)

WBY J. M. Hone, W. B. Yeats $1865-1939$ (1942; rev. ed. 1962). References are to the 1962 edition.

WMA Giorgio Melchiori, The Whole Mystery of Art (1960)

$Y$ Harold Bloom, Yeats (1970)

Y\&GI Donald T. Torchiana, Yeats and Georgian Ireland (1966)

Y\&T $\quad$ F. A. C. Wilson, W. B. Yeats and Tradition (1958)

YCE W. B. Yeats 1865-1939 Centenary Essays, ed. D. E. S. Maxwell and S. B. Bushrui (1965)

YCI B. Rajan, W. B. Yeats. A Critical Introduction (1965)

YI F. A. C. Wilson, Yeats's Iconograpby (1960)

Y:MoM Richard Ellmann, Yeats: the Man and the Masks (1948; rev. ed. 1961). References are to the 1948 edition.

$Y: M \sigma P \quad$ A. Norman Jeffares, Yeats: Man and Poet (1949, rev. ed. 1962). References are to the 1962 edition.

YTDR David R. Clark, W. B. Yeats and the Theatre of Desolate Reality (1965)

YTP Peter Ure, Yeats the Playwright (1963)

YV Helen Hennessy Vendler, Yeats's Vision and the Later Plays (1963)

YVP S. B. Bushrui, Yeats's Verse Plays: The Revisions 1900Igro (1965)

YW Curtis Bradford, Yeats at Work (1965)

JOURNALS

DUM Dublin University Magazine

ELH Journal of English Literary History

NO National Observer 
xiv $\quad A$ Commentary on the Collected Plays of W. B. Yeats

PMLA Publications of the Modern Language Association of America

REL Review of English Literature

RES Review of English Studies

SO Scots Observer 


\section{Chronology of Yeats's Life}

I865 William Butler Yeats, the son of John Butler Yeats and his wife, Susan (née Pollexfen), born at Georgeville, Sandymount Avenue, Dublin, 13 June.

1867 John Butler Yeats moves with his family to 23 Fitzroy Road, Regent's Park, London. Robert (d. 1873), John Butler (Jack), Elizabeth Corbet (Lolly) were born here. Susan Mary (Lily), the elder daughter, was born at Sligo. Frequent visits were made to Sligo to Mrs Yeats's parents, the Pollexfens.

1874 The family moves to 14 Edith Villas, West Kensington.

I875 Yeats goes to the Godolphin School, Hammersmith. Holidays spent in Sligo.

I876 The family moves to 8 Woodstock Road, Bedford Park.

1880 John Butler Yeats's income from lands in Kildare ceases because of Land War. Family returns to Ireland, is lent Balscadden Cottage, Howth, Dublin. W. B. Yeats goes to the High School, Harcourt Street, Dublin (until 1883).

I88 I Family moves to Island View, small house overlooking Howth Harbour. Yeats thinks himself in love with his cousin Laura Johnston.

1883 W. B. Yeats enters School of Art, Dublin.

r88 5 Family moves to ro Ashfield Terrace, off Harold's Cross Road, Dublin. First published poems and an article on esoteric Buddhism appear in the Dublin University Review. Founder member of Dublin Hermetic Society. Becomes friend of Katharine Tynan and John O'Leary.

I886 First experience of séance. Attacks Anglo-Irish, begins 
to read Irish poets who wrote in English and translations of Gaelic sagas.

1887 Family moves to 58 Eardley Crescent, Earls Court, London. Mrs Yeats has two strokes. W. B. Yeats visits William Morris at Kelmscott House. Joins London Lodge of Theosophists.

1888 Family installed in 3 Blenheim Road, Bedford Park (J. B. Yeats's home till 1902). Last of Yeats family land sold in accordance with Ashbourne Act (1888). Contributions to American journals. Visits Oxford to work in Bodleian. Joins esoteric section of Theosophists.

1889 Mild collapse. Prepares selections for Walter Scott. The Wanderings of Oisin and Other Poems. Visits W. E. Henley, meets Oscar Wilde, John Todhunter, York Powell, John Nettleship, and Edwin Ellis (with whom he decides to edit Blake's poems). Edits Fairy and Folk Tales of the Irish Peasantry. Meets Florence Farr. Maud Gonne visits Bedford Park; he falls in love with her; offers to write The Countess Catbleen for her.

1890 'The Lake Isle of Innisfree'. Asked to resign from Theosophists. Initiated into the Order of the Golden Dawn.

189I Representative Irish Tales. Jobn Sherman and Dboya. The Rhymers' Club founded in London. Friendship with Johnson and Dowson. Asks Maud Gonne to marry him. She goes to France. He meets her on her return on ship with Parnell's body. Writes poem on Parnell. Founds London-Irish Literary Society with T. W. Rolleston. Founds National Literary Society in Dublin with John O'Leary as President.

1892 The Countess Katbleen and Various Legends and Lyrics. Irish Fairy Tales.

1893 The Celtic Twilight. The Works of William Blake (ed. Ellis and Yeats, 3 vols).

1894 First visit to Paris; stays with MacGregor Mathers and 
proposes to Maud Gonne again. Sees Axel. Meets 'Diana Vernon'. Revises The Countess Catbleen in Sligo while staying with George Pollexfen and conducting experiments with symbols. The Land of Heart's Desire produced. Visits Gore-Booths at Lissadell.

1895 Poems. Not on good terms with Dowden and Mahaffy. Lionel Johnson drinking heavily. Shares rooms in the Temple with Arthur Symons for a few months (between 1895 and 1896 , date uncertain).

1896 Takes rooms in Woburn Buildings; affair with 'Diana Vernon' lasts a year. Visits Edward Martyn with Arthur Symons, meets Lady Gregory, visits Aran Islands. Meets Synge in Paris, when there to found order of Celtic Mysteries. Member of I.R.B.; forms idea of uniting Irish political parties.

I 897 The Adoration of the Magi. The Secret Rose. Disturbed by effects of Jubilee Riots in Dublin. Visits Coole; collects folklore there with Lady Gregory; writing The Speckled Bird (unpublished novel).

1898 Accompanies Maud Gonne on tour of Irish in England and Scotland. Forms idea of creating Irish Theatre with Lady Gregory and Edward Martyn.

1899 The Wind Among the Reeds. In Paris, again proposes marriage to Maud Gonne. The Countess Catbleen and Martyn's Heather Field produced in Ancient Concert Rooms, Dublin, as programme of Irish Literary Theatre.

1900 Proposes marriage to Maud Gonne in London. Leaves I.R.B. (probably in 1900). Forms new order of Golden Dawn after trouble with Mathers and Aleister Crowley. Helps George Moore to rewrite Martyn's The Tale of a Town, which became The Bending of the Bough.

1902 Lectures on the psalteries. Diarmuid and Grania written in collaboration with George Moore. Becomes President of Irish National Dramatic Society. Catbleen ni Houliban performed in Dublin with Maud Gonne in title role. 
xviii $\quad A$ Commentary on the Collected Plays of W. B. Yeats

r903 Maud Gonne marries John MacBride. The Countess Catbleen, The Pot of Broth and The Hour Glass produced in visit of Irish National Dramatic Company to London. First lecture tour in U.S., arranged by John Quinn.

roos Abbey Theatre opens with Yeats as producer-manager. The King's Threshold and On Baile's Strand.

I905 Limited company replaces National Theatre. Co-director with Lady Gregory and Synge.

1906 Stories of Red Hanraban. Poems I 895-1905.

I907 Crisis over Synge's The Playboy of the Western World. Visits Italy with Lady Gregory and her son. Works on The Player Queen.

I908 Collected Works (in 8 vols). Stays with Maud Gonne in Normandy. Father goes to New York.

I910 Resigns managership. Crisis in affair with unmarried woman. The Green Helmet and other poems.

I9I I Accompanies Abbey players to U.S.

I912 Stays with Maud Gonne in Normandy. Meets Ezra Pound.

1913 Receives Civil List pension of $f$ 150 p.a. Poems Written in Discouragement (dealing with Lane Gallery controversy). Stays at Stone Cottage, Holmans Hatch, Sussex, in autumn with Ezra Pound.

I914 Visits U.S. (January). Returns for Ezra Pound's marriage to Mrs Shakespear's daughter. Investigates miracle at Mirabeau with Maud Gonne MacBride and the Hon. Everard Fielding (June). Responsibilities: poems and a play. Becomes interested in family history; finishes Reveries (first part of Autobiographies).

I9I5 Hugh Lane goes down with Lusitania. Refuses knighthood.

I9I 6 With Ezra Pound (winter). First of the Plays for Dancers 
produced in Lady Cunard's house, London (March). Easter Rising. Writes 'Easter 1916'. In Normandy proposes marriage to Maud Gonne. Reads French poets with Iseult Gonne.

1917 Buys Castle at Ballylee. Proposes to Iseult Gonne. Marries Georgie Hyde-Lees on 21 October. The Wild Swans at Coole.

I9I 8 They stay at Oxford, then Glendalough, then visit Sligo; stay at Coole (and supervise restoration of tower), later at 73 St Stephen's Green (Maud Gonne's house) until December. Per Amica Silentia Luae.

1919 Anne Butler Yeats born (26 February) in Dublin. Summer at Ballylee. Winter spent in Oxford in Broad Street.

1920 American lecture tour until May. Yeats in Ireland in autumn.

192 I Michael Butler Yeats born (22 August). Michael Robartes and the Dancer. Four Plays for Dancers.

1922 Buys Georgian house, 82 Merrion Square, Dublin. J. B. Yeats dies in New York. D.Litt. of Dublin University. Spends summer at Ballylee. The Trembling of the Veil. Later Poems. The Player Queen. Becomes Senator of Irish Free State.

1923 Nobel Prize for Poetry. Visits Stockholm in December for award of Nobel Prize.

1924 Essays. The $C a t$ and the Moon and certain poems. Year mainly spent in final work on $A V$ ision. Reading history and philosophy. High blood pressure. Visits Sicily (November).

1925 Visits Capri, Rome, Milan (February). May at Ballylee. Reading Burke and Berkeley. Speech on divorce in Senate. $A$ Vision (dated 1925, published January 1926).

1926 Estrangement. Chairman of Coinage Committee in Senate. 
Visits St Otteran's School in Waterford ('Among School Children').

1927 Ballylee in summer. October Blast. Congestion of lungs (October). Algeciras, Seville (lung bleeding). Cannes.

1928 Cannes (till February). The Tower. Rapallo (April). Dublin house sold. Ballylee (June). Furnished house at Howth (July). Last Senate Speech (July).

I929 Rapallo (winter). Summer in Ireland, in flat (Fitzwilliam Square, Dublin), at Coole and Ballylee, then at Howth. $A$ Packet for Eqra Pound (August). The Winding Stair (October). Rapallo. Malta fever (December). Ezra Pound and George Antheil at Rapallo.

I930 Portofino (April). Writes 'Byzantium'. Renvyle, Connemara (June). Coole. Words upon the Window-pane produced at Abbey Theatre (November). Visits Masefield at Boar's Hill, Oxford, thirtieth anniversary of their first meeting. Spends winter in Dublin, in furnished house on Killiney Hill.

I93 I Writes 'The Seven Sages'. D.Litt. at Oxford (May). Writes much verse at Coole in summer. Broadcast B.B.C. Belfast (September). Spends winter at Coole, reading Balzac; Lady Gregory dying.

I932 Works on 'Coole Park and Ballylee 1931'. Winter and spring at Coole. Lady Gregory dies. Foundation of Irish Academy of Letters (September). Last American tour (October). Words for Music Perbaps and other poems (November).

I933 Leases Riversdale, Rathfarnham, Co. Dublin. Interested in O'Duffy's blueshirt movement. The Winding Stair and other poems (September). Collected Poems (November).

I934 Steinach operation. Rapallo (June). Rome (autumn). Wheels and Butterflies. Collected Plays. The King of the Great Clock Tower.

I935 Majorca (winter). Shri Purohit Swami collaborates in 
translation of Upanishads there. Dramatis Personae. A Full Moon in March (November).

1936 Seriously ill; heart missing beat (January); nephritis. Returns to Riversdale. Broadcasts on modern poetry, B.B.C., London (summer).

I937 Elected member Athenaeum. Broadcasts B.B.C. London (April, July, September). A Speech and Two Poems (August). Visits Lady Gerald Wellesley. Oxford Book of Modern $V$ erse (1892-1935). A Vision (October). Mentone (winter). Essays $1931-1936$ (December).

1938 The Herne's Egg (January). Visits Sussex, stays with Lady Gerald Wellesley, and with Edith Shackleton Heald. New Poems (May). Sussex (June). Last public appearance at Abbey Theatre for performance of Purgatory (August). Maud Gonne visits him at Riversdale (late summer). Sussex (September).

1939 Dies 28 January, buried at Roquebrune. Last Poems and Two Plays (June). On the Boiler.

I948 Body reinterred at Drumcliffe Churchyard, Sligo. 


\section{The Contents of the Collected Plays}

Page numbers in bold are those of the Collected Plays; those of the Commentary are in ordinary figures.

THE COUNTESS CATHLEEN

THE LAND OF HEART'S DESIRE

CATHLEEN NI HOULIHAN

THE POT OF BROTH

THE KING'S THRESHOLD

THE SHADOWY WATERS

DEIRDRE

AT THE HAWK'S WELL

THE GREEN HELMET

ON BAILE'S STRAND

THE ONLY JEALOUSY OF EMER

THE HOUR-GLASS

THE UNICORN FROM THE STARS

$\begin{array}{rr}\text { I } & \text { I } \\ 5 & 22\end{array}$

$73 \quad 27$

$89 \quad 37$

I05 40

$145 \quad 58$

$169 \quad 72$

$2058 \mathrm{I}$

22196

24599

$279 \quad 106$

$297 \quad \mathrm{I} 24$

$325 \quad 132$

THE PLAYER QUEEN

385 I4I

THE DREAMING OF THE BONES

$43 I \quad I 53$

CALVARY

$447 \quad 166$

THE CAT AND THE MOON

$459 \quad 172$

SOPHOCLES' KING OEDIPUS

$473 \quad 177$

SOPHOCLES' OEDIPUS AT COLONUS $\quad 519 \quad 187$

THE RESURRECTION

THE WORDS UPON THE WINDOW-PANE

$577 \quad 194$

595220

A FULL MOON IN MARCH

619246

THE KING OF THE GREAT CLOCK TOWER

631253

THE HERNE'S EGG

643266

PURGATORY

$679 \quad 274$

THE DEATH OF CUCHULAIN

$691 \quad 297$ 


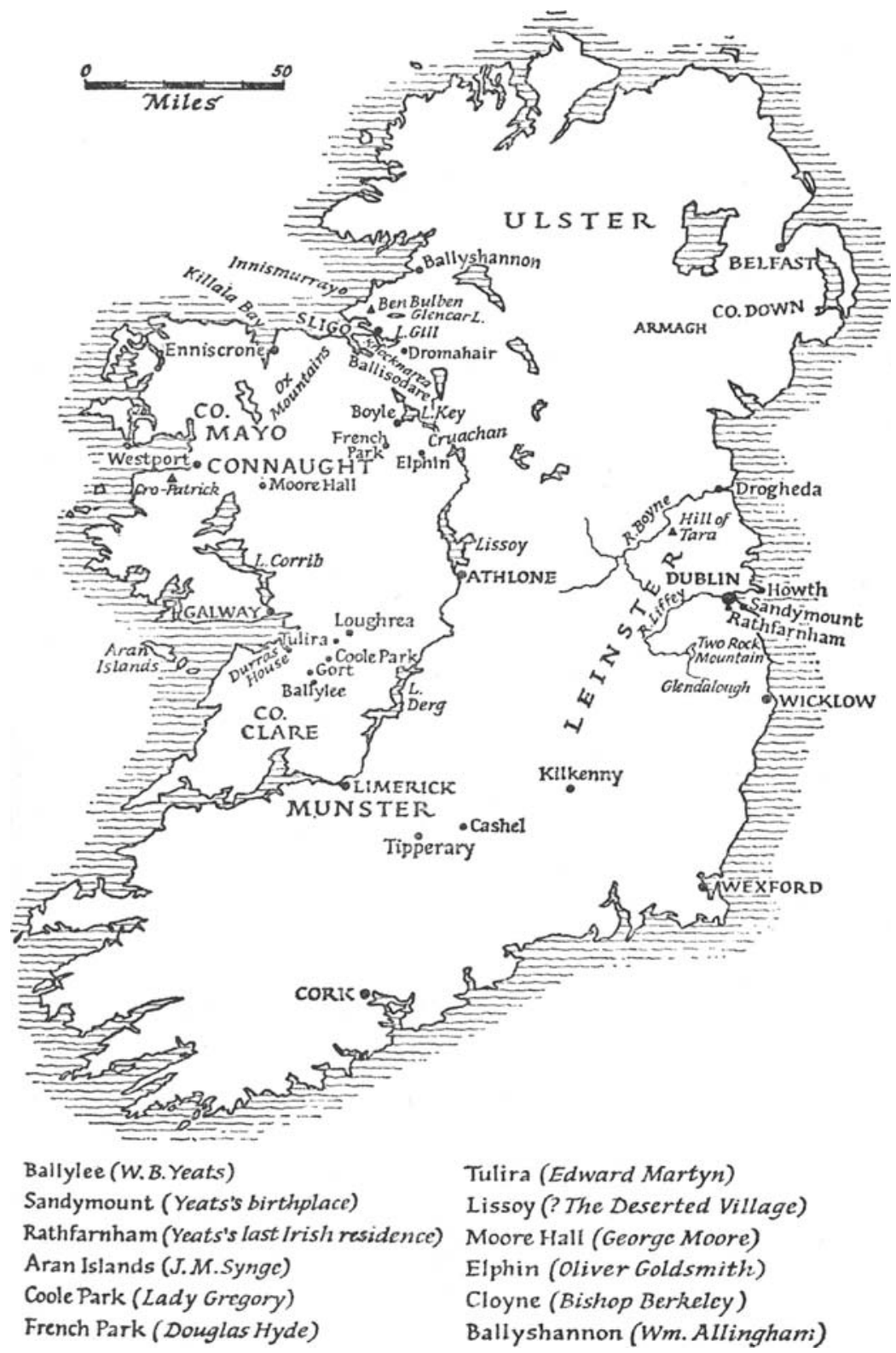

YEATS'S IRELAND 


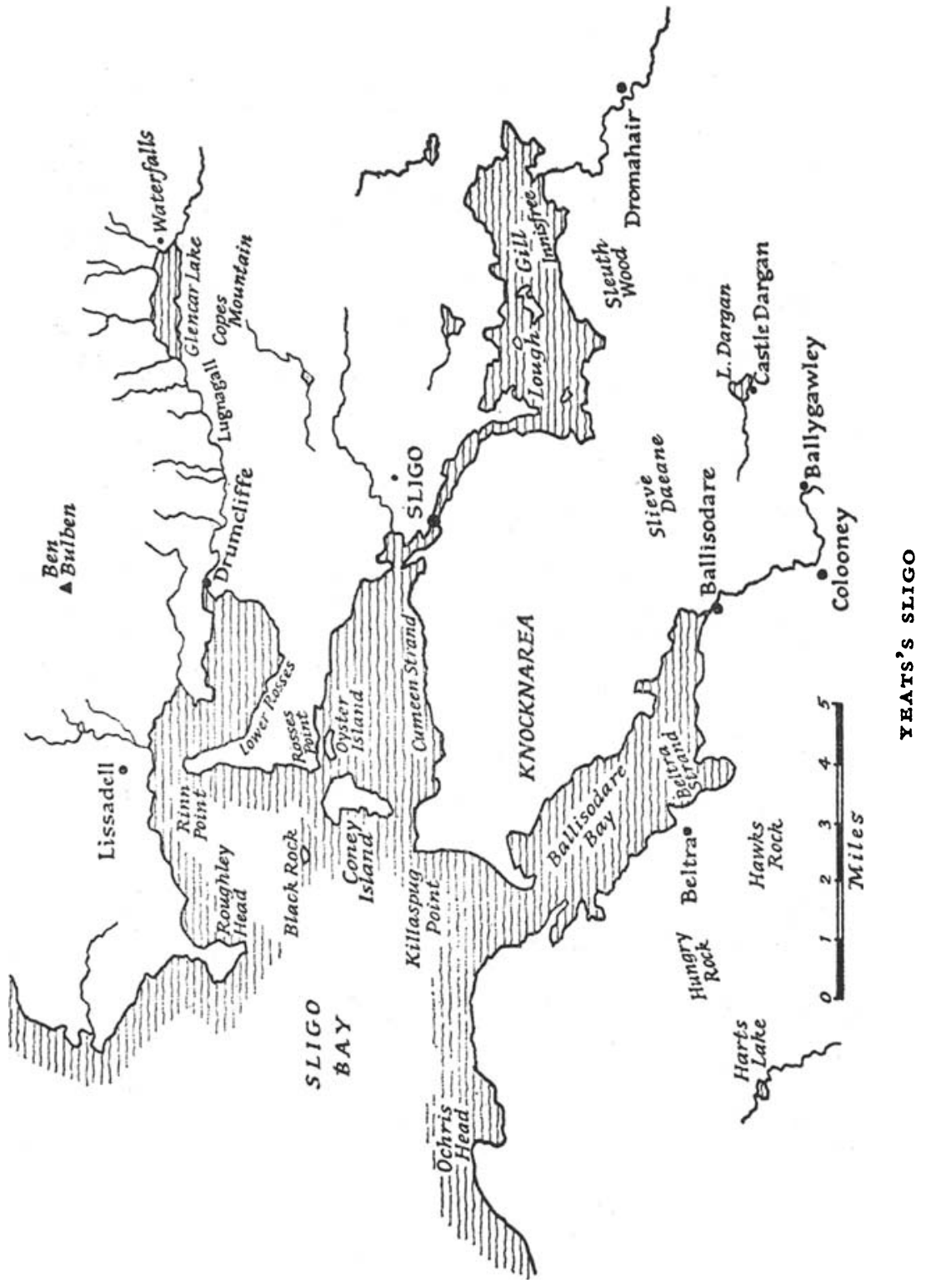

